\title{
In vitro evaluation of selligueain A effects on the pro- inflammatory mediators production in RAW264.7 murine macrophages
}

\author{
Deden Winda Suwandi ${ }^{1,2}{ }^{\circledR}$, Tina Rostinawati ${ }^{3^{\circledR}}$, Muchtaridi Muchtaridi $^{4^{\circledR}}$, Anas Subarnas $^{1^{*}}$ \\ ${ }^{1}$ Department of Pharmacology and Clinical Pharmacy, Faculty of Pharmacy, Universitas Padjadjaran, Jatinangor, Sumedang, Indonesia \\ ${ }^{2}$ Department of Pharmacy, Faculty of Mathematics and Natural Sciences, Universitas Garut, Garut, Indonesia \\ ${ }^{3}$ Department of Pharmaceutical Biology, Faculty of Pharmacy, Universitas Padjadjaran, Jatinangor, Sumedang, Indonesia \\ ${ }^{4}$ Department of Pharmaceutical Analysis and Medicinal Chemistry, Faculty of Pharmacy, Universitas Padjadjaran, Jatinangor, Sumedang, Indonesia
}

\section{AR T I C L E I N F O}

Article Type:

Original Article

\section{Article History:}

Received: 22 October 2020

Accepted: 20 April 2021

\section{Keywords:}

Polypodium feei

Selligueain A

In vitro

Anti-inflammatory activity

\begin{abstract}
A B S T R A C T
Introduction: Selligueain A derived from the roots of Polypodium feei was shown to have antiinflammatory activity, which was tested in vivo on the rats' paw edema induced by carrageenan. The aim of this study was to evaluate the anti-inflammatory mechanism of selligueain A in vitro against the production of pro-inflammatory mediators.

Methods: In this study, RAW264.7 cells were used as an inflammatory cell model, and observations were made on the inflammatory mediators nitric oxide (NO), inducible nitric oxide synthase (iNOS), and tumour necrosis factor- $\alpha$ (TNF- $\alpha$ ). The NO concentration was measured by the Griess reaction, and the iNOS enzyme and the TNF- $\alpha$ concentrations were determined by the ELISA method. Cell viability was assessed by the [3-(4,5-dimethylthiazol-2yl)-5-(3-carboxymethoxyphenyl)-2-(4-sulfophenyl)-2H-tetrazolium] (MTS) test.

Results: Selligueain A at concentrations of 100 and $150 \mu \mathrm{M}$ suppressed the production of NO, iNOS, and TNF- $\alpha$ in RAW264.7 cells stimulated by lipopolysaccharide (LPS). The concentration of $150 \mu \mathrm{M}$ showed the highest inhibition of NO, iNOS, and TNF- $\alpha$ mediators with the percentage inhibition of $64.85,55.01$, and $48.54 \%$, respectively.

Conclusion: This study shows that selligueain A has anti-inflammatory activity through inhibition of NO, iNOS, and TNF- $\alpha$ production in RAW264.7 macrophage cells.
\end{abstract}

Implication for health policy/practice/research/medical education:

Selligueain A of the $P$. feei roots had anti-inflammatory activity through the inhibition of the production of inflammatory mediators, NO, iNOS, and TNF- $\alpha$. The results will encourage further researches to complement scientific evidence regarding the efficacy of Selligueain A, as an anti-inflammatory agent.

Please cite this paper as: Suwandi DW, Rostinawati T, Muchtaridi M, Subarnas A. In vitro evaluation of selligueain A effects on the pro-inflammatory mediators production in RAW264.7 murine macrophages. J Herbmed Pharmacol. 2021;10(3):313-318. doi: $10.34172 /$ jhp.2021.36.

\section{Introduction}

Inflammation is a physiological disorder of the body, which includes an increase in leukocytes and inflammatory mediators in certain tissues. Inflammation occurring for a long time will cause chronic inflammation, such as decreased immune system, degenerative diseases, and cancer (1). The response of inflammation has an important role in the pathogenesis of several diseases initiated by tissue injury and caused by the invasion of pathogenic microorganisms or free radicals that can cause vascular and cellular reactions. Macrophages play an important role in the inflammatory response. They are the main source in producing pro-inflammatory cytokines such as tumour necrosis factor- $\alpha$ (TNF- $\alpha$ ), nitric oxide (NO), interleukins (IL) and inflammatory mediating enzymes such as cyclooxygenase (COX) and inducible nitric oxide synthase (iNOS) (2). Overexpression of iNOS through activation of macrophages is the mechanism responsible for NO synthesis during inflammation. The free radical NO mediates the physiological and pathophysiological 
processes of inflammation. TNF- $\alpha$ is a cytokine that signals an inflammatory response. Inhibition of inflammation is an important target to prevent the occurrence of diseases in the body, especially diseases mediated by inflammation such as cancer, diabetes mellitus, neurological disease, autoimmune disease, and arthritis (1). One of the most common inflammatory diseases in the world is arthritis, which is characterised by pain, swelling and stiffness in the joints (3).

Polypodium feei METT., (synonym: Selliguea feei) is a plant of the genus of Polypodium in the Polypodiaceae family. This genus is widely spread throughout the world, with the highest species diversity in the tropics. P. feei is a fern plant that grows in forests, in open areas, among rocks, mostly at 900-3150 m altitude. In the Java islands, it grows especially on volcanoes, near craters, because it is resistant to volcanic fumes, and occurs in abundance around the crater of the Tangkuban Perahu mountain in West Java of Indonesia (4).

In traditional medicine, the roots or rhizomes of $P$. feei are commonly used to facilitate urination, treat rheumatism, lower blood pressure, or exert an aphrodisiac effect. Baek et al reported a trimeric proanthocyanidin constituent of the $P$. feei roots, named selligueain A, which was rated highly sweet by a taste panel and not toxic for mice in the preliminary acute toxicity test. In our previous study, selligueain A showed analgesic and anti-inflammatory activities in mice and rats. Also, its proanthocyanidin fraction inhibited COX activity (4). The molecular docking proved that proanthocyanidin afzelechin (a monomer of selligueain A) could interact with Met522 of Cox-1 and 2 by the hydrogen binding (5).

The aim of this study was to evaluate anti-inflammatory mechanism of action of selligueain A isolated from the P. feei roots against the RAW264.7 cells stimulated by lipopolysaccharide (LPS). The macrophage RAW264.7 cells of LPS-stimulated mice were used as an inflammatory cell model.

\section{Materials and Methods}

Materials

Selligueain A was isolated from the P. feei roots. Aquabidest, Dulbecco's modified Eagle's medium/DMEM (Biowest ${ }^{\circledR}$ ), $10 \%$ fetal bovine serum/FBS (Biowest ${ }^{\circledR}$ ), 1\% antibiotic and antimycotic/ABAM (Biowest ${ }^{\circledR}$ ), sel RAW 264.7 (ATCC ${ }^{\circledR}$ TIB-71), mouse TNF- $\alpha$ ELISA kit (ElabScience ${ }^{\circledR}$ ), mouse NOS2/iNOS ELISA Kit (ElabScience ${ }^{\circledR}$ ), Kit NO assay (ElabScience ${ }^{\circledR}$ ), micropipette (Finnpipette ${ }^{\mathrm{TM}}$ F2), spectrofotometer (GO Thermo Scientific ${ }^{\circledR}$ ), vortex $\left(\right.$ Wisemix $\left.^{\circledR}\right)$, Tips Blue, yellow, white (Neptune Scientific ${ }^{\circledR}$ ), and microtube $1.5 \mathrm{~mL}$ (SPL) were used in this study.

Extraction and isolation of selligueain A

The dried powders of the $P$. feei roots $(4.5 \mathrm{~kg})$ were extracted with methanol by a maceration method at room temperature. The extraction was carried out three times and each time of extraction was for 24 hours. The methanol extract was concentrated by evaporation of the solvent under lower pressure at the temperature of $50^{\circ} \mathrm{C}$ to get a concentrated extract $(1232.7 \mathrm{~g})$. The extract was fractionated by partitioning method using the $n$-hexane-water (3:1) and ethyl acetate-water (3:1) mixture successively to give the fractions of $n$-hexane, ethyl acetate, and water $(60.12,513.75$, and $298.6 \mathrm{~g}$, respectively). Based on our previous work (4), the targeted selligueain A compound was contained in the ethyl acetate fraction, so isolation work was conducted on the ethyl acetate fraction. The ethyl acetate fraction was column chromatographed using the mixture of $n$-hexane, ethyl acetate, and methanol as a mobile phase and silica gel 60 as a stationary phase to give 10 fractions. The fraction 6 that was predicted to contain selligueain A was further subjected to column chromatography using the mixture of chloroform-methanol (10:0, 9:1, 8:2, 7:3, and 6:4) as eluent to obtain the selligueain A. The spectroscopic spectral data (UV, IR, MS, and NMR) of the isolated compound were analysed to identify the compound which was confirmed by comparison of its data with those reported in the literature (6).

Cell culture

RAW264.7 cells of a murine macrophage were cultured in DMEM supplemented in $10 \% \mathrm{FBS}, 100 \mathrm{U} / \mathrm{mL}$ penicillin, and $100 \mathrm{~g} / \mathrm{mL}$ streptomycin. Cells were grown to a confluence of $80 \%-90 \%$ and applied to no more than 20 cell passages, afterward the cells were acclimatised for 12 hours before any use (7).

\section{Measurement of RAW264.7 cell viability}

Cell viability was determined by MTS assay. About $80 \%-$ $90 \%$ of confluent cells were discarded and washed with PBS 1x. PBS for rinsing was removed and added $1 \mathrm{~mL}$ of Trypsin-EDTA $0.25 \%$. The mixture was incubated at $37^{\circ} \mathrm{C}$ for 3 minutes, so that the cells were detached from the bottom of the flask. Checking was done using an inverted microscope to ensure that the cells have been completely detached from the bottom of the flask. Two $\mathrm{mL}$ of complete growth medium was added to stop the trypsinization process. The cells were put into a $15 \mathrm{~mL}$ centrifuge tube and centrifuged at $1600 \mathrm{rpm}$ for 5 minutes. The supernatant was removed, and the pellet was resuspended with $1 \mathrm{~mL}$ growth medium. Cell resuspension was calculated using haemocytometer. After knowing the number of cells at $1 \mathrm{~mL}$ of previous cell resuspension, $5 \times 10^{3}$ cells/well cells were planted on a 96 well plate. The cells were incubated at $37^{\circ} \mathrm{C}, 5 \% \mathrm{CO}_{2}$ to $80 \%-90 \%$ confluent cells. If it was confluent, the samples at various doses $(200,150,100,50$, $25,12.5$, and $6.25 \mu \mathrm{M})$ were given and then incubated at $37^{\circ} \mathrm{C}, 5 \% \mathrm{CO}_{2}$ for 24 hours. After a 24 hours treatment, 20 $\mu \mathrm{L}$ MTS was added, and incubated for 3 hours at $37^{\circ} \mathrm{C}, 5 \%$ 
$\mathrm{CO}_{2}$. The absorbance was recorded at a wavelength of 490 $\mathrm{nm}$, and optical densities were determined at $490 \mathrm{~nm}$ by means of a microplate reader (8).

\section{Measurement of NO}

The RAW264.7 cells were seeded in 96-well plates (2 $\times 10^{5}$ cells $/ \mathrm{mL}$ ) and incubated at $37^{\circ} \mathrm{C}$ in a humidified atmosphere with $5 \% \mathrm{CO}_{2}$. Twelve hours after treatment, the cells were treated with various concentrations of selligueain $\mathrm{A}(10,100$, and $150 \mu \mathrm{M})$ for 1 hours and afterward LPS $(1 \mu \mathrm{g} / \mathrm{mL})$ was added for 24 hours. Before heading to the NO test reaction, pre-treatment was carried out. In the standard and sample tubes, various concentrations of Sodium Nitrite Standard were added (To $150 \mu \mathrm{L}$ was added $200 \mu \mathrm{L}$ reagent 1 and $100 \mu \mathrm{L}$ reagent 2 ). All reagents were mixed and incubated for 15 minutes at room temperature, then centrifuged ( $3100 \mathrm{~g}, 10$ minutes). A total of $160 \mu \mathrm{L}$ supernatant was inserted in 96 wellplates and added $80 \mu \mathrm{L}$ chromogenic reagent. All reagents in the well were shaken for 2 minutes and incubated for 15 minutes at room temperature. The NO test results were read at OD $550 \mathrm{~nm}$ (9).

\section{Determination of TNF- $\alpha$ by ELISA}

TNF-a level in each sample was determined using a commercially available ELISA kit, and assays were conducted in accordance with the manufacturer's instructions. Briefly, the cells were cultured in 24-well plates $\left(5 \times 10^{5} \mathrm{cell} / \mathrm{mL}\right)$ for 12 hours, pre-incubated for 1 hour with various concentrations of selligueain $A$, and stimulated with LPS $(1 \mu \mathrm{g} / \mathrm{mL})$ for 24 hours. Cell culture supernatants obtained were immediately quantified by means of ELISA kits based on the manufacturer's instructions. The standard solution was placed in each well twice as much as $100 \mu \mathrm{L}$, covered with a seal and incubated for 90 minutes at $37^{\circ} \mathrm{C}$. Next, the solution was discarded and immediately added with biotinylated detection absolution of $100 \mu \mathrm{L} /$ well, then covered and incubated for 1 hour at $37^{\circ} \mathrm{C}$. The solution was discarded and washed with Wash Buffer, waited in 1-2 minutes then discarded-repeated three times. After cleaning, $100 \mu \mathrm{L} /$ well HRP conjugate was added and the plate was covered and incubated for 30 minutes at $37^{\circ} \mathrm{C}$. The plate was washed five times. Then, $90 \mu \mathrm{L} /$ well substrate was added and incubated for 15 minutes at $37^{\circ} \mathrm{C}$. If the colour was not changed, the incubation time was added but not until 30 minutes. The $50 \mu \mathrm{L} /$ well stop solution was added to each well. Optical density (OD) was measured at $450 \mathrm{~nm}$ using a spectrophotometer (10).

\section{Determination of iNOS by ELISA}

iNOS level in each sample was measured using a commercially available ELISA kit, and assays were carried out based on the manufacturer's instructions. Briefly, the cells were cultured in 24-well plates for 12 hours, pre-incubated for 1 hour with various concentrations of selligueain A, then stimulated with LPS $(1 \mu \mathrm{g} / \mathrm{mL})$ for 24 hours. Cell culture supernatants were collected and immediately quantified using ELISA kits in accordance with the manufacturer's instructions. The standard solution was placed in each well twice as much as $100 \mu \mathrm{L}$, then covered with a seal, and incubated for 90 minutes at $37^{\circ} \mathrm{C}$. Next, the solution was discarded and a Biotinylated Detection Absolution of $100 \mu \mathrm{L} /$ well was immediately added, covered, and incubated for 1 hour at $37^{\circ} \mathrm{C}$. The solution was discarded and washed with Wash Buffer, then waited for 1-2 minutes and discarded-repeated three times. After cleaning, $100 \mu \mathrm{L} /$ well HRP conjugate was added, and the plate was covered and incubated for 30 minutes at $37^{\circ} \mathrm{C}$. The plate was washed five times. Then, 90 $\mu \mathrm{L} /$ well substrate was added and incubated for 15 minutes at $37^{\circ} \mathrm{C}$. If the colour was not changed, incubation time was added but not until 30 minutes. The $50 \mu \mathrm{L} /$ well stop solution was added to each well. OD was measured at 450 $\mathrm{nm}$ using a spectrophotometer (11).

\section{Statistical analysis}

Data were analysed by one-way analysis of variance (ANOVA) and continued by a post hoc least-significant difference test. The data are presented as mean \pm standard deviation. A $P$ value of less than 0.05 was considered significantly different.

\section{Results}

Identification of selligueain A

Selligueain A is a known compound of the P. feei roots. The identification of this compound was just conducted by analyzing its spectroscopic spectral data (UV, IR, MS, and NMR) and comparing its data with those reported in the literature (6). Its structure is shown in Figure 1.

In vitro examination of the anti-inflammatory property of Selligueain A

An examination of selligueain A against the production of pro-inflammatory mediators on RAW 264.7 makrofag cells was initially conducted by determining cell viability, followed by measuring the NO, TNF, and iNOS levels.

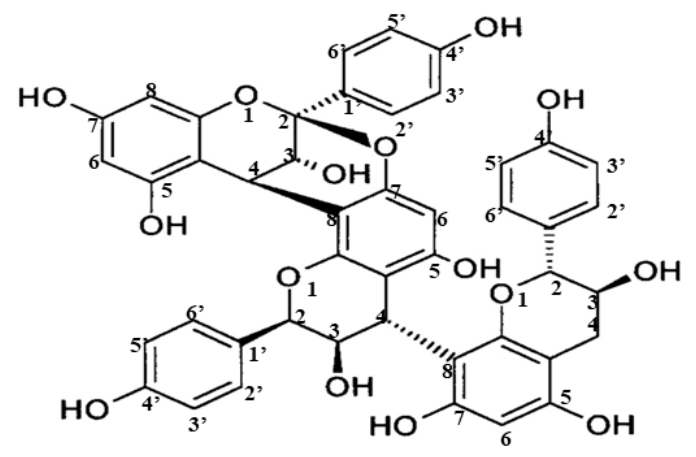

Figure 1. Structure of selligueain $A$. 
Measurement of RAW264.7 cell viability

The data of the RAW264.7 cell viability measurement are shown in Figure 2. Selligueain A did not cause cell death at any concentration used $(6.25,12.5,25,50,100,150$, and $200 \mu \mathrm{M})$ on RAW264.7 cells.

Inhibition of NO release from LPS-stimulated RAW264.7 cells

Inhibition of selligueain A against NO release from LPSstimulated RAW264.7 cells is shown in Figure 3. Selligueain A at the concentrations of 100 dan $150 \mu \mathrm{M}$ decreased NO levels significantly as compared to the control $(P<0.05)$. The percentage inhibition of each concentration $(10,100$, and $150 \mu \mathrm{M}$ ) showed a concentration-dependent manner (28.43, 57.30, and $64.85 \%$, respectively).

Inhibition of iNOS enzyme in RAW264.7 cells

Selligueain A was examined for its inhibition on the synthesis of iNOS enzyme, which is responsible as a provider and synthesizer of NO inflammatory mediators. The iNOS enzyme is a physiological element that can initiate inflammation. Selligueain A at the concentrations of 100 dan $150 \mu \mathrm{M}$ decreased iNOS levels significantly

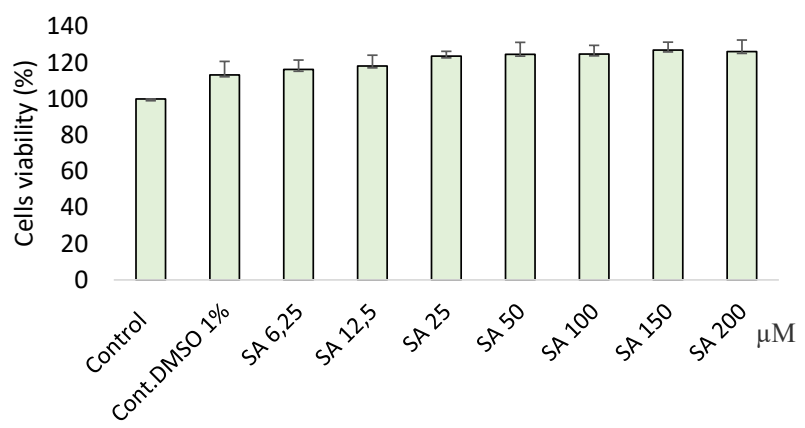

Figure 2. Viability of RAW264.7 cells. SA: Selligueain A. Control: cells without lipopolysaccharide (LPS) and selligueain A. Cont.DMSO 1\%: cells with LPS and DMSO $1 \%$. SA 6.25 to $200 \mu \mathrm{M}$ : cells with LPS and 6.25 to $200 \mu \mathrm{M}$ concentration of selligueain $\mathrm{A}$.

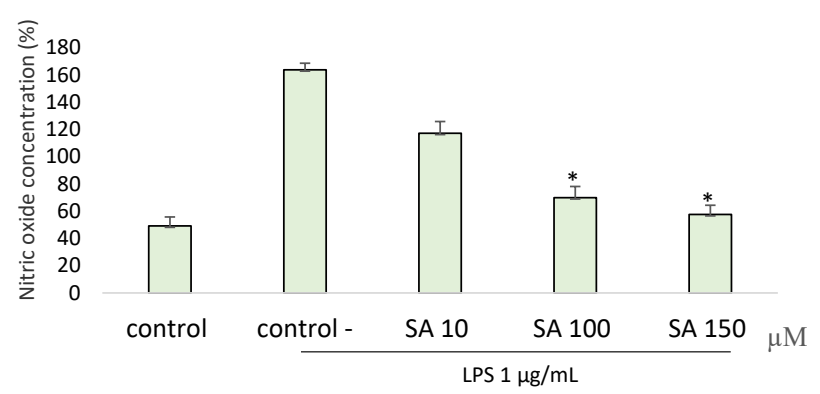

Figure 3. The concentration of Nitric oxide (NO) in RAW264.7 cells. SA: Selligueain A. Control: cells without lipopolysaccharide (LPS) and selligueain A. Control -: cells with LPS and DMSO 1\%. SA 10: cells with LPS and selligueain A of $10 \mu \mathrm{M}$. SA 100: cells with LPS and selligueain A of $100 \mu \mathrm{M}$. SA 150: cells with LPS and selligueain A of $150 \mu \mathrm{M}$. * Significantly different from the negative control according to ANOVA test $(P<0.05)$. as compared to the control $(P<0.05)$ (Figure 4$)$. The percentage inhibition of each concentration $(10,100$, and $150 \mu \mathrm{M}$ ) showed a concentration-dependent manner (26.35, 30.89 and 55.01\%, respectively).

Inhibition of TNF production in LPS-stimulated RAW264.7 cells

The inhibition of selligueain A against TNF- $\alpha$ production in LPS-RAW264.7 cells is shown in Figure 5. Among the examined concentrations $(10,100$, and $150 \mu \mathrm{M})$, the concentration of $150 \mu \mathrm{M}$ decreased TNF- $\alpha$ production significantly as compared to the control $(P<0.05)$. The percentage inhibition of each concentration was 11.41, 27.78 , and $48.54 \%$.

\section{Discussion}

The evaluation of anti-inflammation of a test compound in vitro could be conducted by examining its inhibitory

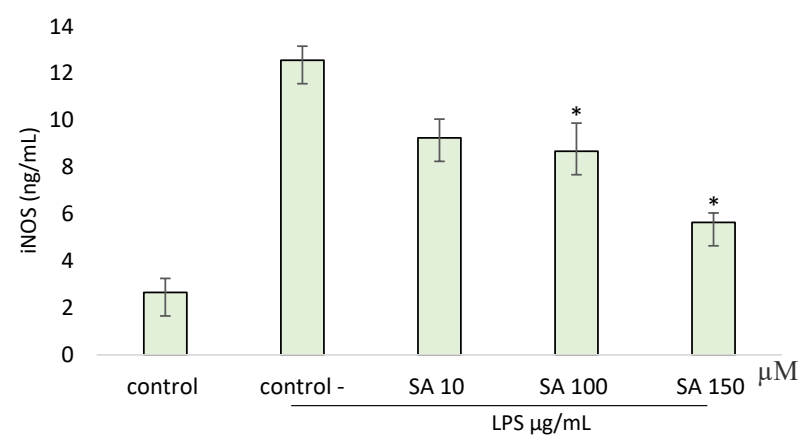

Figure 4. The concentration of nitric oxide synthase (iNOS) in RAW264.7 cells. SA: Selligueain A. Control: cells without lipopolysaccharide (LPS) and selligueain A. Control -: cells with LPS and DMSO 1\%. SA 10: cells with LPS and selligueain A of $10 \mu \mathrm{M}$. SA 100: cells with LPS and selligueain A of $100 \mu \mathrm{M}$. SA 150: cells with LPS and selligueain A of 150 $\mu \mathrm{M}$. ${ }^{*}$ Significantly different from the negative control according to ANOVA test $(P<0.05)$.

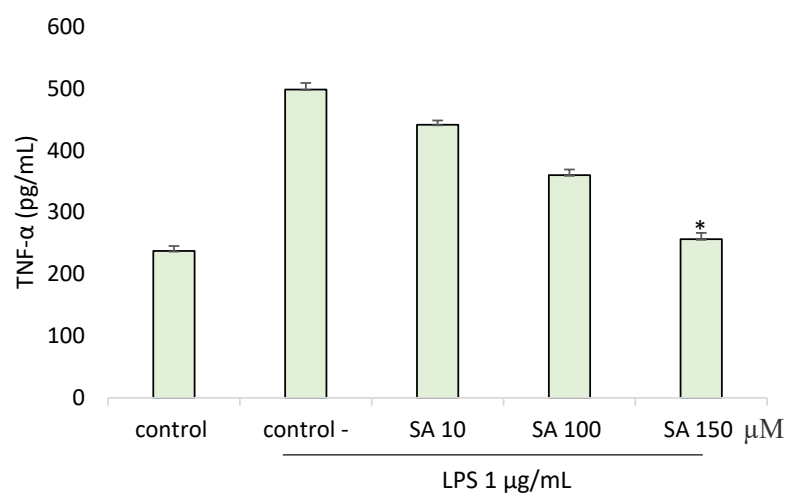

Figure 5. The concentration of tumour necrosis factor- $\alpha$ (TNF- $\alpha$ ) in RAW264.7 cells. SA: Selligueain A. Control: cells without lipopolysaccharide (LPS) and selligueain A. Control -: cells with LPS and DMSO $1 \%$. SA 10: cells with LPS and selligueain A of $10 \mu \mathrm{M}$. SA 100: cells with LPS and selligueain A of $100 \mu \mathrm{M}$. SA 150: cells with LPS and selligueain A of $150 \mu \mathrm{M}$. * Significantly different from the negative control according to ANOVA test $(P<0.05)$. 
activity against the inflammatory mediator production, such as NO, iNOS, and TNF-a on RAW 264.7 cells induced by LPS. The existence of macrophage cells in the inflammatory process is one of the cellular responses that play a role in body defense. Macrophages participate in initiating the inflammatory response during inflammation. The process involves the production of inflammatory mediators such as cytokines TNF- $\alpha$, interleukins, prostaglandins, NO, and the enzymes such as COX and iNOS. These enzymes are useful in protecting the body from the infection or tissue damage $(1,12)$. These mediators have an important role in the pathogenesis of acute and chronic inflammation (13). The production of cytokines and pro-inflammatory enzymes can be stimulated by LPS, an endotoxin component of gramnegative bacteria (14).

In this study, the selligueain A inhibition against the inflammatory mediator production was firstly examined by the toxicity test on the RAW264.7 cells using an MTS method. The test indicated no cell death caused by selligueain A at any concentration used.

Further testing was conducted on the inhibitory activity of selligueain A against the production of NO, iNOS, and TNF- $\alpha$ in LPS-induced RAW 264.7 cells. Inhibition of the production of these mediators is one of the targets to explore the mechanisms of action of anti-inflammatory drugs. Selligueain A at the concentrations of 100 and 150 $\mu \mathrm{M}$ inhibited NO production (indicated by the decrease in NO levels) was significantly different when compared to the control group. The inflammatory mediator NO is derived from the amino acid L-arginine by the iNOS enzyme. Drugs that can inhibit NO production can treat acute and chronic inflammatory symptoms $(15,16)$.

In line with the inhibitory activity on NO production, the iNOS enzyme inhibition test was also carried out. Selligueain A at the concentrations of 100 and $150 \mu \mathrm{M}$ reduced levels of iNOS enzyme protein, which was different from the control group. The RAW 264.7 cells, when induced by LPS, produced the iNOS enzyme to synthesize the inflammatory mediator NO.

Subsequent tests carried out on TNF- $\alpha$ showed that selligueain $A$ at the concentration of $150 \mu \mathrm{M}$ could significantly reduce the levels of TNF- $\alpha$ cytokines with the percentage inhibition value of $48.54 \%$. TNF- $\alpha$ is a cytokine that can bind to receptors on the surface of target cells that play a role in ongoing inflammation. TNF- $\alpha$ can activate macrophages/monocytes, fibroblasts, mast cells, $\mathrm{T}$ cells, and natural killer cells. TNF- $\alpha$ can also trigger fever through stimulation of PGE2 synthesis in vascular endothelial cells and the hypothalamus. The continued presence of TNF- $\alpha$ has been reported to be responsible for a group of chronic inflammatory diseases such as parasite infections, cancer, and rheumatoid arthritis (17).

Overall data indicated that selligueain A was proven to reduce NO, iNOS, and TNF- $a$ levels of RAW264.7 macrophage cells induced by LPS. These findings may be related to the anti-inflammatory mechanism of selligueain A, which was previously reported (4).

\section{Conclusion}

Selligueain A of the $P$. feei roots had anti-inflammatory activity through the inhibition of the production of inflammatory mediators, NO, iNOS, and TNF- $\alpha$, the highest activity of which was shown by the concentration of $150 \mu \mathrm{M}$. These results increase scientific proof of the pharmacological activity of the $P$. feei roots.

\section{Authors' contributions}

DWS made research designs, conducted all research experiments, compiled and processed data and wrote the scripts. TT assisted in conducting in vitro experiments and biomarker analysis. $M$ supervised the extraction and isolation processes. AS directed the development of research designs and organized all stages of the experiment.

\section{Conflict of interests}

The authors declare no conflict of interest.

\section{Ethical considerations}

The experimental protocols were approved by the Research Ethics Committee of Faculty of Medicine, Universitas Padjadjaran, Indonesia, with the ethical clearance number of 325/UNG.KEP/EC/2019.

\section{Funding/Support}

Source of funding was the Ministry of Research and Technology and Higher Education, Jakarta, Indonesia. (Grant number: 1827/UN6.3.1/LT/2020).

\section{References}

1. Park SB, Park GH, Um Y, Kim HN, Song HM, Kim N, et al. Wood-cultivated ginseng exerts anti-inflammatory effect in LPS-stimulated RAW264.7 cells. Int J Biol Macromol. 2018;116:327-34. doi: 10.1016/j.ijbiomac.2018.05.039.

2. Damte D, Reza MA, Lee SJ, Jo WS, Park SC. Antiinflammatory activity of dichloromethane extract of Auricularia auricula-judae in RAW264.7 cells. Toxicol Res. 2011;27(1):11-4. doi: 10.5487/tr.2011.27.1.011.

3. Afrin SR, Islam MR, Proma NM, Shorna MK, Akbar S, Hossain MK. Quantitative screening of phytochemicals and pharmacological attributions of the leaves and stem barks of Macropanax dispermus (Araliaceae) in treating the inflammation and arthritis. J Herbmed Pharmacol. 2021;10(1):75-83. doi: 10.34172/jhp.2021.07.

4. Subarnas A, Wagner H. Analgesic and anti-inflammatory activity of the proanthocyanidin shellegueain A from Polypodium feei METT. Phytomedicine. 2000;7(5):401-5. doi: 10.1016/s0944-7113(00)80061-6.

5. Hasanah AN, Levita J, Natapoera ED, Subarnas A. Analyzing the interaction of shellegueain A: a bioactive compound of Pakis tangkur (Selliguea feei or Polypodium 
feei) to cyclooxygenase enzyme by molecular docking. Asian J Chem. 2011;23(7):3093-6.

6. Baek NI, Chung MS, Shamon L, Kardono LB, Tsauri S, Padmawinata K, et al. Selligueain A, a novel highly sweet proanthocyanidin from the rhizomes of Selliguea feei. J Nat Prod. 1993;56(9):1532-8. doi: 10.1021/np50099a011.

7. Lee M, Shim SY, Sung SH. Triterpenoids isolated from Alnus japonica inhibited LPS-induced inflammatory mediators in HT-29 cells and RAW264.7 cells. Biol Pharm Bull. 2017;40(9):1544-50. doi: 10.1248/bpb.b16-00895.

8. McGowan EM, Alling N, Jackson EA, Yagoub D, Haass NK, Allen JD, et al. Evaluation of cell cycle arrest in estrogen responsive MCF-7 breast cancer cells: pitfalls of the MTS assay. PLoS One. 2011;6(6):e20623. doi: 10.1371/journal. pone. 0020623 .

9. Lee CW, Kim SC, Kwak TW, Lee JR, Jo MJ, Ahn YT, et al. Anti-inflammatory effects of bangpungtongsung-san, a traditional herbal prescription. Evid Based Complement Alternat Med. 2012;2012:892943. doi: 10.1155/2012/892943.

10. Huang J, Qin Y, Liu B, Li GY, Ouyang L, Wang JH. In silico analysis and experimental validation of molecular mechanisms of salvianolic acid A-inhibited LPS-stimulated inflammation, in RAW264.7 macrophages. Cell Prolif. 2013;46(5):595-605. doi: 10.1111/cpr.12056.

11. Endrinaldi E, Darwin E, Zubir N, Revilla G. The effect of mesenchymal stem cell Wharton's jelly on ADAMTS-4 and iNOS levels in osteoarthritis rat model. Open Access Maced J Med Sci. 2019;7(8):1270-5. doi: 10.3889/oamjms.2019.155.

12. Kim E, Yi YS, Son YJ, Han SY, Kim DH, Nam G, et al.
BIOGF1K, a compound K-rich fraction of ginseng, plays an antiinflammatory role by targeting an activator protein-1 signaling pathway in RAW264.7 macrophagelike cells. J Ginseng Res. 2018;42(2):233-7. doi: 10.1016/j. jgr.2018.02.001.

13. Andreakos E, Sacre SM, Smith C, Lundberg A, Kiriakidis S, Stonehouse T, et al. Distinct pathways of LPS-induced NF-kappa B activation and cytokine production in human myeloid and nonmyeloid cells defined by selective utilization of MyD88 and Mal/TIRAP. Blood. 2004;103(6):2229-37. doi: 10.1182/blood-2003-04-1356.

14. Pinho-Ribeiro FA, Verri WA Jr, Chiu IM. Nociceptor sensory neuron-immune interactions in pain and inflammation. Trends Immunol. 2017;38(1):5-19. doi: 10.1016/j.it.2016.10.001.

15. Millet P, Opiekun M, Martin T, Beauchamp GK, Kimball BA. Cytokine contributions to alterations of the volatile metabolome induced by inflammation. Brain Behav Immun. 2018;69:312-20. doi: 10.1016/j.bbi.2017.12.005.

16. Garcia R, Ferreira JP, Costa G, Santos T, Branco F, Caramona $\mathrm{M}$, et al. Evaluation of anti-inflammatory and analgesic activities of Cymbopogon citratus in vivopolyphenols contribution. Res J Med Plants. 2015;9(1):113. doi: 10.3923/rjmp.2015.1.13.

17. Wu J, Qu Y, Deng JX, Liang WY, Jiang ZL, Lai R, et al. Resveratrol inhibition of TNF- $\alpha$ and IL- 1 for treatment of rheumatoid arthritis: from in-silico to in-vitro elucidation. Int J Clin Exp Med. 2016;9(2):745-52. 